腎性続発性上皮小体機能元進症に対する上皮小体摘出術

一術前カルシゥム負荷試験と組織像からみた手術適応についてー

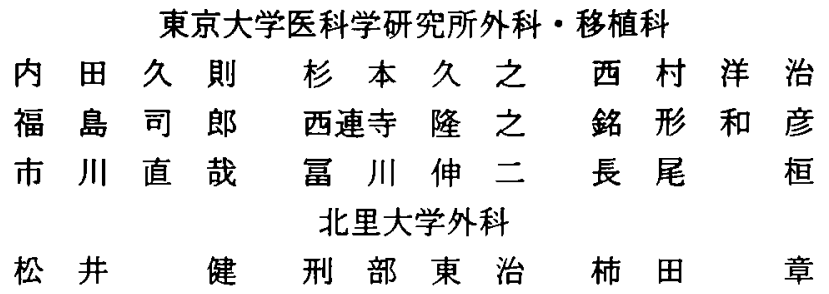

術前のカルシウム負荷試験が手術適応決定に有用か否かを検討する目的で，上皮小体 摘出術を行った50例の腎性上皮小体機能六進症につき分析を行った。摘出上皮小体の重 量は43例が 1 グラム以上 $(3.87 \pm 0.42 \mathrm{SEgram}), 7$ 例が 1 グラム以下 $(0.81 \pm 0.05 \mathrm{SE}$ gram)であった，組織学的には，1グラム以上の重量の第 1 群は有意に nodular hyperplasia 像を示し，第 2 群は diffuse hyperplasia 像であった $(\mathrm{p}<0.05)$. 術前にカルシウ ム負荷試験では，第 1 群が負荷後 1 時間で inteact-PTH 値は前值の $55 \pm 5.6 \%$ む゙の低 下にとどまったのに対して，第 2 群では $33 \pm 4.9 \%$ ま゙低下し，この差は有意であった $(\mathrm{p}<0.01)$. 組織学的に nodular hyperplasia で重量が 1 ダラム上小例を手術適応と考 え, diffuse hyperplasia で重量が 1 クラム以下の例を保存的治療の適応と考えれば，術 前のカルシウム負荷試験は両群の鑑別に役立つと結論しうる。

索引用語：堅性上皮小体機能穴進症，手術適応，カルシゥム負荷試験, nodular hyperplasia, diffuse hyperplasia

はじめに

進行した腎性上皮小体機能え進症に対して，上皮小 体摘出術は急速に臨床症状の改善をるたらすが，その 外科的手術適応に関しては必ずしも確立していない。 とくに最近では, 活性ビタミンD大量療法により上皮 小体機能六進の病態改善がすたらされることが明らか になり121，保存的治療法として一般化されつつある。 このような現状で，どのような症例を手術適応とする べきか、明確にする必要がある。

従来上皮小体機能六進の指標として血清カルシウ ム、イオン化カルシウム、リン, アルカリフォスフ ターゼ, C-PTH 值, 血漿 intact.PTH 值等が用いられ, また直接的には上皮小体の著しい重量増加か，臨床症 候あるいは徽候とともに，手術適応判定の基準として 用いられてきた ${ }^{3)-5)}$.しかし，摘出前の状態では上皮小 体重量の正確な測定はできず，あくまです推定にとど

1992年11月 5 日受付 1993年 5 月 6 日採用
まることになる．術前の生化学検査値と摘出上皮小体 重量との相関については多くの報告があるが3167)，機 能え進状態が手術適応か否かとい5境界領域では, 必 ずしも確実な指標となり得ないる8.

上皮小体機能のもら一つの指標は，カルシゥム負荷 に対し PTH 分泌がどの程度抑制されるかといらカル シウム負荷試験であるか，続発性上皮小体機能六進症 におけるこの面からの検討はきわめて少ない.9．それ 故, 術前のカルシウム負荷圾験と摘出上皮小体の重量 ならびに組織学的所見との相互関俰を明らかにし，手 術適応基準が得られるか否かにつき検討を行った。

\section{対象と方法}

\section{対象症例}

1978年12月より1992年 1 月までに北里大学外科拉よ び東京大学医科学研究所外科・移植科の 2 施設で上皮 小体摘出術を行った堅性上皮小体機能六進症50例を対 象とした。症例の29例は男性, 21例は女性で，手術時 の年齢は26歳から64歳で平均 $42.8 \pm 9.3(\mathrm{SD})$ 歳であっ 
Table 1 Parathyroidectomy on Secondary Hyperparathyroidism due to Renal Failure

\begin{tabular}{lcc}
\hline \multicolumn{2}{l}{ Number of patients } & 50 \\
Sex & Male & \\
Age & Female & 29 \\
Duration of hemodialysis & 21 \\
(months) & $42.8 \pm 9.3$ (SD) \\
\hline
\end{tabular}

た。睛不全による透析期間は27カ月から153カ月で, 平

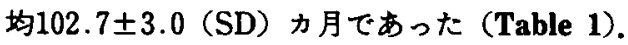

症例の $96 \%$ は安静時あるいは運動時の骨関節痛を訴 之，17\%の症例では多発性骨折が認められた。皮庙搔

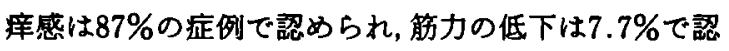
められた。

また, いずれの症例す全身骨 X 線像で緎維性骨炎所 見かi明瞭で, echogram, computed tomography, $\mathrm{T}^{201}$ scintigram 像など画像診断所見において畽大した上 皮小体が認められ，血清 C.PTH あるいは血䈋 intactPTHの著しい高値が認められた。

C-PTH, intact-PTH, イオン化カルシゥムの測定 血清 C-PTH, 血漿 intact-PTH, イオン化カルシウム の測定はすでに報告した方法で行っだ．すなわち， C-PTH は RIA キット (Baxter), intact-PTH は RIA キット(Dainabot)，イオン化カルシゥムはイオン電極 法により測定した。

\section{カルシウム負荷試験}

43症例において上皮小体摘出前にカルシウム負荷試 験を実施した。 $15 \mathrm{mg} / \mathrm{kg} /$ 体重のカルシウムを生理的 食塩水に加え，全量を $500 \mathrm{ml}$ とし，4時間で点滴により 静脈内投与を行った $(125 \mathrm{ml} / \mathrm{hour})$.カルシウム剤とし てはクルコン酸カルシウム(カルチコール®，カルシウ

厶量 $7.85 \mathrm{mg} / \mathrm{ml}$ )を用いた。

いずれす堅不全で無尿の患者のため，検査の際の急 速な容量負荷を避けるため, 血液透析中に負荷試験を 行った。

カルシウム負荷前と負荷後 $1 ， 2 ， 3 ， 4$ 時間に採 血し，カルシウム、イオン化カルシウム、C-PTH, intact-PTHの测定を行った。すへてての検査が実施で きたのは38症例である.

上皮小体摘出手術と合併手術

手術術式としては術中最小限 4 個の上皮小体を確認 するように検索を行い，全例胸腺舌状部を摘出するよ うに配虑した。すし 3 腺しか確認できないときには，
発見できない側の甲状腺側葉を切除し，甲状腺組織内 の上皮小体の有無をチェックした．50例中 4 例で，初 回手術では上皮小体が 3 個しか確認できず，5ち1例 では緥隔開創の再手術で残りの 1 個を発見し, 摘出し ている.

初期の14例では上皮小体亜全摘手術，すなわちる。 とも小さい上皮小体の $1 / 2$ - 1/3を残す7/8切除を行っ た.しかしこの方法では間もなく $\mathrm{PTH}$ 再上昇が認め られ，手術的に不充分であると判明したため，その啳 の例では上皮小体全摘を行い,むっとも小さい上皮小 体の30 -50mg 量を上腕三頭筋内に移植する方法を 行った.

摘出上皮小体は直ちに湿性重量を測定し，丑速診断 で上皮小体であることを確認し, 永久標本で HE 染色 により病理組織学的に検索した。

また，50例中 5 例で甲状腺腺腫， 2 例で甲状腺乳頭 癌の合併が認められ, 甲状腺側葉切除あるいは甲状腺 垔全摘とリンパ節郭清術を行った。

摘出上皮小体重量, 徒前カルシウム負荷試験と病理 組織学的所見との相互関係

われわれのこれまでの検討で9)，摘出上皮小体重量 が 1 グラム以上と以下でカルシウム負荷試験に対応す る intact-PTH の分泌抑制の程度が異なることが明ら かであったため，今回の検討でも摘出上皮小体重量 1 ダラムの第 1 群 (Group 1) と上皮小体重量く 1 ダラ ムの第 2 群 (Group 2) に分けて患者年龄, 性別, 透析 期間などの背景因子の分析, ならびに上皮小体摘出前 の血清カルシゥム, イオン化カルシゥム, リン, アル カリフォスファターゼ, C-PTH 值および血䈋 intactPTH 值について両群に統計的有意差が認められるか 否かにつき娭討した。 また，カルシウム負荷試験の結 果について両群に有意差が認められるかどらかにつき 検討した。

実際には症例43以降は，患者選択に扰いて，カルシ ウム負荷試験の結果 intact-PTH 分泌の抑制が充分で ない症例を手術適応として意图的に選んである。した がって，ここで有意差が認められる可能性は検討前か ら充分予測されていた。

また，摘出上皮小体の病理組織学的所見で, nodular hyperplasia か diffuse hyperplasia かによって両群に 有意差が認められるかどらか検討した. Fig. 1 に示し たごとく典型的 nodular hyperplasia 像，また，Fig. 2 に示したごとく典型的 diffuse hyperplasia 像でもっ てその判定の基準とした. 摘出上皮小体のうち 1 腺で 


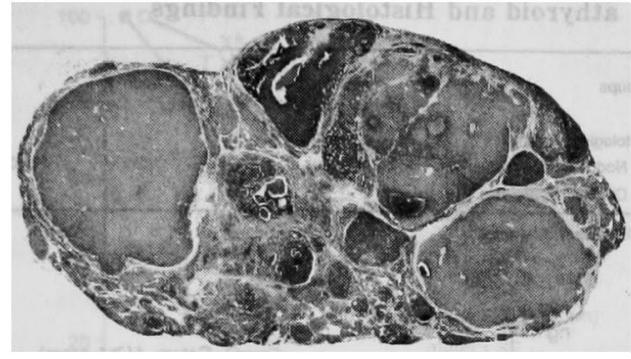

Fig. 1 Histopathological findings of the parathyoid gland removed from a 43 year-old female patient. Total weight of the gland reached to $5.85 \mathrm{~g}$. Note the typical nodular hyperplasia of the gland. If minimal nodular hyperplastic pattern is observed as shown on this figure, the parathyroid of the patient is categorized to nodular hyperplasia.

もわずかに nodular hyperplasia の所見が認められた 場合，その症例は nodular hyperplasia に分類した。

結果

\section{手術所見}

手術において 4 腺が摘出できたのが 43 例， 5 腺が 3 例， 6 腺が 1 例で， 3 腺しか摘出できなかったのが 3 例である。 3 腺しか摘出できなかった症例の5ち2 例 では術後血清カルシウム値が $6 \mathrm{mg} / \mathrm{dl}$ 前後まで低下 し、カルシウム剤と活性ビタミン D 製剤の補充療法が 必要で，上皮小体は全摘されたと判断した。しかし， 他の 1 例では血清カルシゥム値の低下は著しくなく， $8 \mathrm{mg} / \mathrm{dl}$ 前後で，また，C.PTH 値は $5 \mathrm{ng} / \mathrm{ml}$ 前後であ ク，まだ摘出し得なかった 1 腺が残っていると考えら れた。

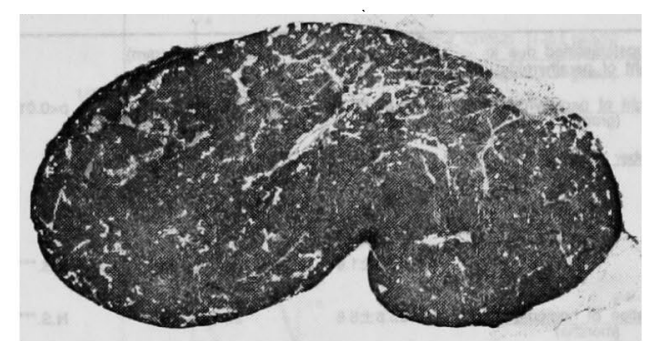

Fig. 2 Histopathological findings of the parathyroid gland removed from a 54 year-old female. Total weight of the gland reached to $0.63 \mathrm{~g}$. Note the typical finding of diffuse hyperplasia. If all glands showed only diffuse hyperplastic pattern as shown on this figure, the parathyroid of the patient is categorized to diffuse hyperplasia.

摘出上皮小体の重量は43例が 1 グラム以上で， 7 例 が 1 グラム以下であった。摘出上皮小体の重量は $0.63 \sim 10.70$ グラムで平均3.23土2.59（SD）グラムで あった（Table 2).

とくにカルシウム負荷試験の結果を加味して手術適 応とした最近の 8 症例では, 摘出上皮小体重量が 10.7 , $7.6 ， 5.8 ４ 4.7,4.7,4.6,4.5,1.9$ グラムといずれる 1.0 グラム以上であった.

\section{両群の背景因子の比較検討}

術前のカルシウム負荷試験が実施された38例につい ては，摘出上皮小体重量が 1 グラム以上の Group 1は 32例， 1 グラム以下の Group 2 は 6 例であった。摘出 上皮小体重量では Group 1が有意に重く（Student $\mathrm{t}$ test, $\mathrm{p}<0.01$ )，患者性別では Group 1が有意に男性が 多かったが（ $x^{2}$ test, $\left.\mathrm{p}<0.05\right)$ ，年龄，血液透析期間

Table 2 Operative Findings in Secondary Hyperparathyroidism due to Renal Failure

\begin{tabular}{cc}
\hline Number of parathyroids found (removed) during surgery & Number of patients \\
3 glands & 3 \\
4 glands & 43 \\
5 glands & 3 \\
6 glands & 1 \\
$<1$ gram & 7 \\
$\geqq 1$ gram & 43 \\
Weight of the removed parathyroid & \\
$3.23 \pm 2.59(\mathrm{SD}) \mathrm{mg}$ & 50 \\
\hline
\end{tabular}


Table 3 Comparisons of Background Factors Between Two Groups

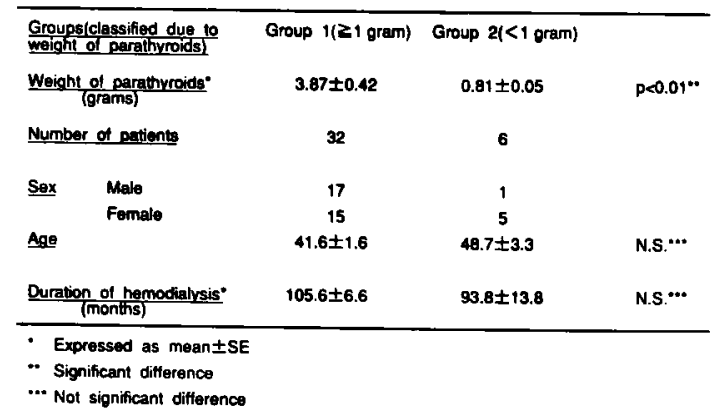

Table 4 Comparison of Preoperative Biochemical Data Between Two Groups

\begin{tabular}{|c|c|c|c|}
\hline & Group 1 (weightz1 gram) & Group 2 (weight< $<1$ gram) & \\
\hline$\frac{\text { Level of serum C.PTH }}{(\mathrm{ng} / \mathrm{mi})}$ & $38.9 \pm 4.4$ & $20.1 \pm 6.7$ & $\rho<0.01 *$ \\
\hline$\frac{\text { Lovel of plasma intact-PTH" }}{(\operatorname{pg})^{*}}$ & $2207 \pm 497.1$ & $981.3 \pm 679.6$ & N.S. ${ }^{-\cdots}$ \\
\hline$\frac{\text { Lovel of senum caleium" }}{(\text { mgrill })}$ & $9.5 \pm 0.2$ & $9.0 \pm 0.3$ & N.S.".: \\
\hline $\begin{array}{l}\text { Level of senum ionized } \\
\text { calcium (mE कL) }\end{array}$ & $2.45 \pm 0.08$ & $2.31 \pm 0.10$ & N.S... \\
\hline$\frac{\text { Level of serum phosphate" }}{(\mathrm{mg} / \mathrm{d})\}}$ & $5.04 \pm 0.27$ & $5.13 \pm 1.12$ & N.S.". \\
\hline $\begin{array}{l}\text { Level of serum alkaline } \\
\text { Dhosphatisat (IUL) }\end{array}$ & $1326.8 \pm 196.0$ & $798.6 \pm 241.8$ & N.S... \\
\hline $\begin{array}{l}\text { - Expressed as mean } \pm S E \\
\text { - Significant difference } \\
\text {... Not significant difference }\end{array}$ & & & \\
\hline
\end{tabular}

\section{については有意差が認められなかった（Table 3).}

\section{両群の術前生化学検查値の比較梌討}

術前の生化学検査値のうち血清 C-PTH 値は有意に Group 1で高值であったが (Student $t$ test, $\mathrm{p}<0.01$ ), その他の検査値では有意差が認められなかった

(Table 4).

\section{両群の組樴学的所見についての比較梌討}

総重量が 1 タラム以上の Group 1では30例が nodular hyperplasia 像を示し, わずか 2 例が diffuse hyperplasia 像を示したに過ぎず，また，その重量はそ れぞれ1.30と1.52クラムであった。一方，1クラム以 下の Group 2では 2 例が nodular hyperplasia 像を示 したが，5ち1例はる51腺が残っている可能性のあ る症例である。一方 4 例では diffuse hyperplasia 像で あった。この両者の差は統計的に有意であった（ $\chi^{2}$ test, $\mathrm{p}<0.01$ ) (Table 5).

両群のカルシウム負荷試験についての比較検討

カルシウム負荷試験の際にとくに異常所見は認めら れず，患者はすべてこの検查に耐之得た。
Table 5 Relationships Between Weight of Parathyroid and Histological Findings

\begin{tabular}{|c|c|c|c|}
\hline Groups & $\begin{array}{c}\text { Group } 1 \\
\text { (weight:1 gram) }\end{array}$ & $\begin{array}{c}\text { Group } 2 \\
\text { (welght< }<\text { gram) }\end{array}$ & \\
\hline \multicolumn{4}{|l|}{ Histological findings } \\
\hline Nodular hyperplasia & 30 & 2 & $p<0.01^{\circ}$ \\
\hline Diffuse hyperplasia & 2 & 4 & \\
\hline
\end{tabular}

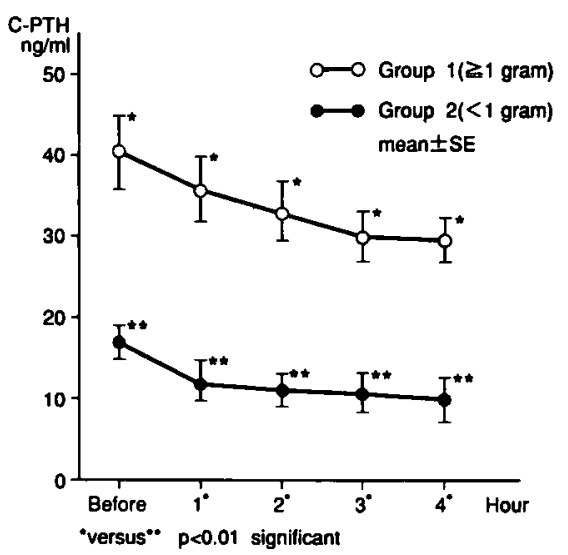

Fig. 3 Responeses of serum C-PTH to calcium infusion in two groups. In patients of group 1 total weight of the removed parathyroid is more than 1 gram and that of group 2 is less than 1 gram. Patients in both groups showed the similar decreasing level of the C-PTH in respones to calcium infusion. However, levels of the C-PTH before and 4-hour after infusion in each group were not significantly different. Levels of the C-PTH at each hour after initiation of calcium infusion were significantly different between groups 1 and 2.

カルシウム負荷に対応して血清カルシウムとイオン 化カルシウム值はそれぞれ前值と比較し $1 \sim 4$ 時間の 間に有意の上昇を示した。

血清 C-PTH 值は両群とも平均的に低下したが, 前 值に比べ最る低值の 4 時間後でも有意の低下ではな かった（いずれる $\mathrm{p}>0.05 ）$ 。しかし，両群の間には各 時間ごとの値に有意差が認められ，Group 1は Group 2に比較し高値を示していた(Student $\mathrm{t}$ test, $\mathrm{p}<0.01$ ) (Fig. 3).

各症例についての血清 C-PTH 值の前値に対する時 間ごとの値をパーセント表示し比較した結果では, Group 2が Group 1より低下を示したが, 両群に有意 の差がなく，また各々の群について 4 時間後でも前値 


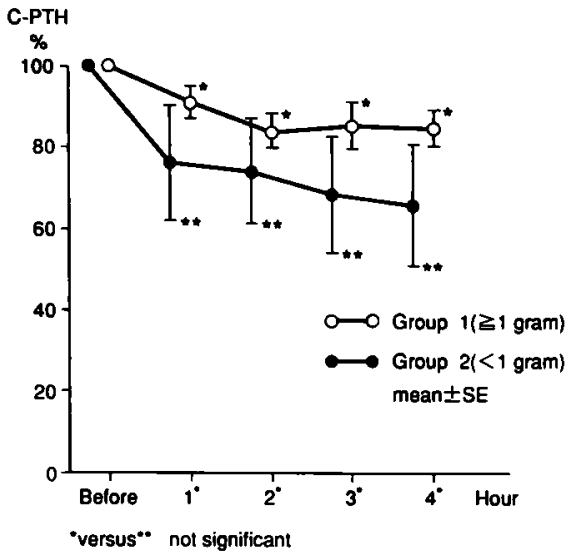

Fig. 4 Percent changes of serum PTH in response to calcium infusion. In patients of group 1 total weight of the removed parathyroid is more than 1 gram and that of group 2 is less than 1 gram. Level of the C.PTH at each hour after starting calcium infusion was expressed as percent of the C.PTH level before the calcium load in each group. No significant changes were observed in levels of the C.PTH in each group and between groups 1 and 2.

に対し有意の低下ではなかった（Fig.4）。

カルシウム負荷に対する intact-PTH の反応はC. PTHの場合と異なり Group 1では前值に対し 1 4 時間それそれが有意の低下を示した（p<0.01）。

一方, Group 2では 2 時間後の值のみ前值に対し有 意の差が認められた。

Group 1と 2 の間での比較では，前値では有意差が 認められなかったが，1〜4時間のそれそれの値の間 で有意差が認められた（Fig. 5)。

また，それぞれの群の各症例で前值を $100 \%$ とて 1 〜 4 時間值を\%表示で示した場合，Group 1は1時間 で intact-PTH の分泌は55土5.6 (SE)\%の抑制にとど まったが, Group 2では33土4.9（SE)\%まで抑制され た（Fig. 6）。この両群の差は有意であった（Student t test, $\mathrm{p}<0.01)$.

次に, 病理組織学的所見で nodular hyperplasia 像 を示した症例と diffuse hyperplasia 像を示した症例 につき，術前のカルシゥム負荷に対する intact-PTH の分泌動態につき比較してみると, nodular hyperplasia 症例では 1 時間後に前值に対し $55 \pm 5.4$ (SE)\% の分泌低下にとどまったが， diffuse hyperplasia 症例 では前值に対し29土3.0(SE)\%をで分泌が抑制された

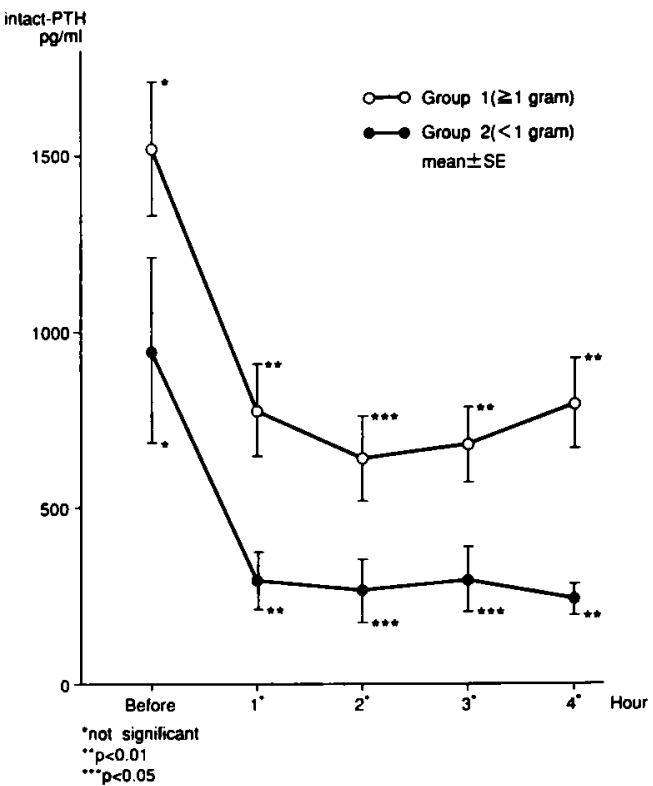

Fig. 5 Responses of plasma intact-PTH to calcium infusion in groups 1 and 2 . In patients of group 1 total weight of the removed parathyroid is more than 1 gram and that of gsoup 2 is less than 1 gram. Difference between levels of the intact-PTH in groups 1 and 2 before calcium infusion was not significant. In both groups, however, levels of the intact-PTH decreased significantly in response to calcium infusion, which was more marked in group 2. As a result significant changes were observed in levels of the intact-PTH at each hour after calcium load between groups 1 and 2 .

(Fig. 7).この両群の差は有意であった（p<0.05）。 考案

堅性上皮小体機能六進症においては，骨病変とそれ に伴ら臨床症状が患者にとって最大の愁訴となる。す なわち，骨塩量の著しい低下により骨質が脆弱となり きわめて僅かな外力から骨折を起こす，もっとも頻繁 に骨折が認められるのは胁骨であり，気道感染による 咳で容易に多発性骨折を起こす。また，大卧骨頸部骨 折あるいは金椎骨の圧迫骨折もしばしば起こり，この 場合歩行障害となるため患者の苦痛はきわめて大き い.

他方，軟部組織へのカルシウムの沈着による異所性 石灰化も認められ，その部にきわめてて強い痛みが起 こるため，患者に苦痛をもたらす。 


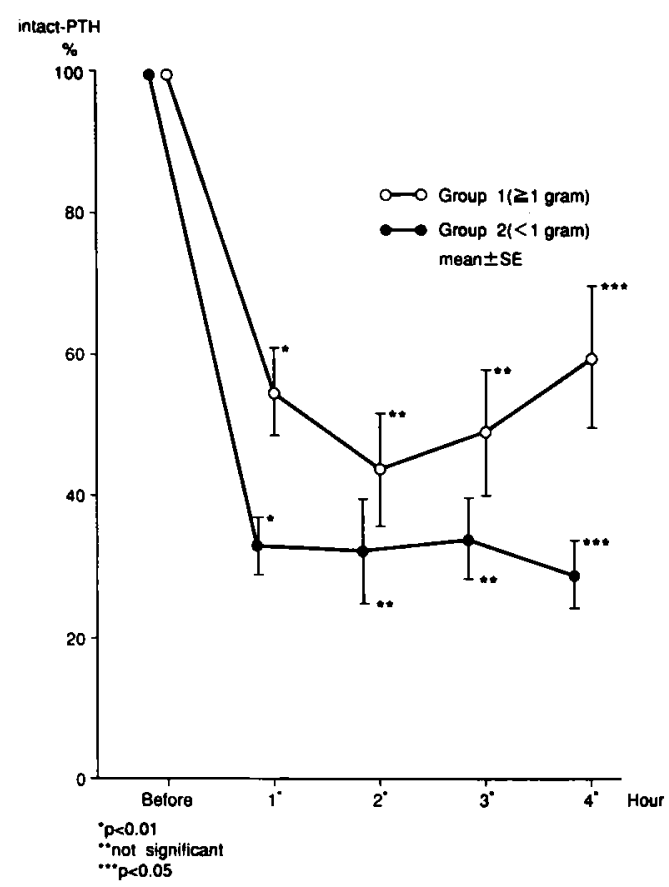

Fig. 6 Percent changes of plasma intact-PTH in response to calcium infusion. In patients of group 1 total weight of the removed parathyroid is more than $1 \mathrm{gram}$ and that of group 2 is less than 1 gram. Level of the intact-PTH at each hour after starting calcium infusion was suppressed as percent of the intact-PTH level before the calcium load in each group. Significant decrease of levels of the intact-PTH was observed at each hour after the calcium load in each group. The intact-PTH level 1 hour after the calcium infusion in group 1 was $55 \pm 5.6 \%$ and the corresponding figure in group 2 was $33 \pm 4.9 \%$, which were different significantly.

しかしこのよらな骨病变は，周知のごとくすべて上 皮小体機能六進症に基つくわけではなく，堅性骨異栄 養症として総称される病因に基つく結果であって, 堅 におけるビタミンD活性化障害による骨軟化症, 長期 の酸血症による脱灰のための骨粗踥症, アルミニウム 沈着によるフルミニウム骨症あるいは $\beta_{2}$-microglobulinの沈着による骨関節症などが上皮小体機能立 進症以外にありらる(0111). したがって骨病变と自覚症 状のみで上皮小体摘出の適応を決めるわけにはいかな いが，骨病変があり明らかに上皮小体機能六進症があ れば，この病変が進行的であるとの考学から，従来は 上皮小体摘出術が行われている。たとえば，われわれ

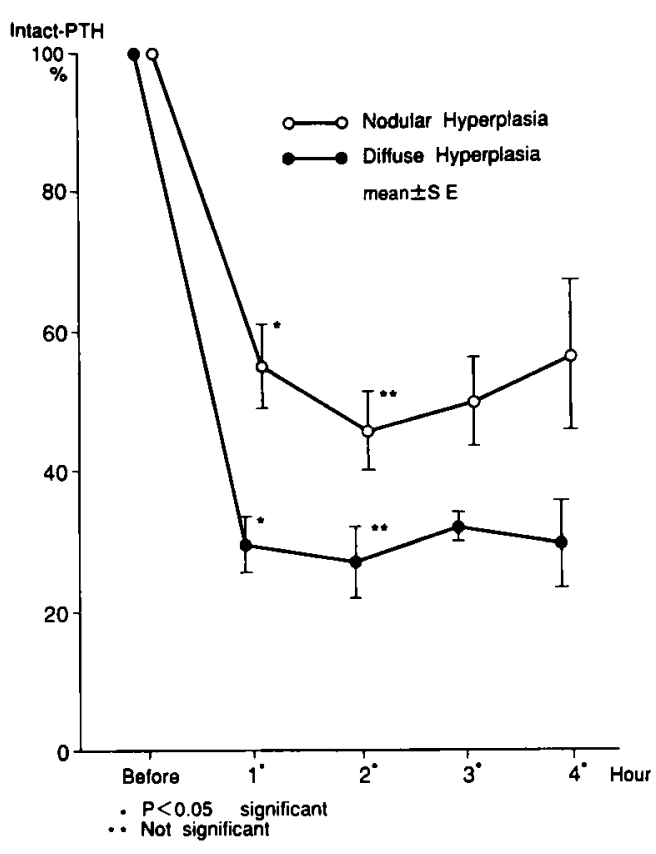

Fig. 7 Percent changes of plasma intact-PTH in respose to calcium infusion are shown between patients with parathyroid of nodular heperplasia and those of diffuse hyperplasia. Levels of the intact-PTH one hour after the calcium load in both groups were different significantly.

の初期の経験では，骨病変として頭骨の顆粒状脱灰が 認められ, 手指の中節骨に骨膜下吸収像が存在し, 血 清 C-PTH 值が $20 \mathrm{ng} / \mathrm{ml}$ 前後であれば, 自覚症状は強 くなくとも上皮小摘出の適応と考光, 外科手術を行。 てきた。

一方, Slatopolsky らは，腎性上皮小体機能六進症に 対し活性ビタミン D の大量静脈内投与を行うと PTH の分泌が抑制され病態の改善がもたらされると報告 し1), 本邦でも Marumoらがこの治療法を追試して同 様な結果を得ている2). Marumo らは活性ビタミンD の静注法の代わりに間欠的経口大量投与法を開発し, この方法により直接的に PTH 分泌が抑制されること を認めた2).

このように堅性上皮小体機能六進症に対し内科的治 療が奏効することが明らかになった現在, 外科手術適 応についての考之る当然以前とは異なり, 新たな概念 の提唱が必要と思われる。この疾患は良性で病態自体 生命が危険となることはなく, 手術的治療は保存的治 療に優先するものではない。 
しかし，今回の報告における症例43から50までの8 症例のらちの 4 例は活性ビタミンDの大量療法にも かかわらず PTHの分泌抑制は充分でなく，骨病変の 改善がなく自覚症状が著しいため手術適応になっだ. また，この症例はすべてカルシウム負荷に対する intact-PTH の分泌抑制は50\%以内に止まり，結果的 に摘出した上皮小体総重量はいずれも5 5゙ラム前後の 著しい機能立進例であった。したがって，活性ビタミ ンDによる保存的治療もすへてての堅性上皮小体機能 六進症に対して効果的なのではなく，おのずと限界が あり, 進行例はむしろ外科的治療の対象と思われる。

手術適応の決定の際問題になる術前の生化学検査値 については，これまでのわれわれの報告あるいは他の 報告におけるごとく，摘出上皮小体重量と統計的に有

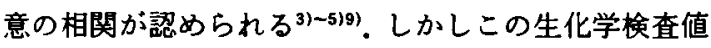
で一定の cut off level を決め，手術適応を決めるには 難点がある. 今回の検討でも明らかなよらに，たとえ ば摘出重量が 1 グラム以上と以下で両群にわけ, 両群 の術前生化学検査値につき有意差の有無につき検討し てみると、C-PTH 值のみが有意差を示したが，その他 の検査値に差は認められなかった。C-PTH 値は確か に上皮小体機能立進の程度を判断する一つの指標とな る.しかし，堅不全における C-PTH 值を上皮小体機能 そのむのを示すむのとして評価するには多少の問題か～ ある.

PTH でホルモン活性が認められるのは $\mathrm{N}$ 末端にあ ク，C末端ではない，1８4個のアミ/酸すべてが結合 しているのが intact-PTHで，この半減期は短く10分 程度で，分必されて間もなく肝，堅，上皮小体あるい は骨髄中に含まれる cathepsinにより分解され fragment となる ${ }^{22}$.この中でホルモン活性が認められるの はN 末端で少なくとも34個のアミ，酸配列がそろっ ている必要がある13). fragmentになった PTHは，堅 不全においては血中に蓄積し，C-PTH の RIA 法によ る測定キットでこのすへててが測定されるため，測定値 が著しく高くなる。したがってこの高值は必ずしも正 確な上皮小体機能を反映しているとはいえない(14)。た が今回の検討でもむしろこの值が上皮小体総重量の異 なる両群間で有意差を示し,一方, intact-PTH は有意 差を示さなかった。この理由は次のごとく説明できる たろ5. 生化学検查のため透析者の場合一般に透析前 採血が行われるが，必ずしも食前ではなく食後採血む あり，また透析開始後の採血ああり一定していない。 一般に市肘の透析液のカルシウム濃度には4.8 8.2 $\mathrm{mg} / \mathrm{dl}$ のさまざまな商品があり，多くは6.0〜7.0 $\mathrm{mg} /$ dl 前後である ${ }^{15)}$. したがって血清カルシウム値はかな りの変動を示す可能性があり, intact-PTHは鋭敏に カルシゥムの変動に対応して分必の抑制あるいはえ進 を示すことが考えられる. 今回の検討に括いても，力 ルシウム負荷試験の際カルシウム上昇に対応し, intact-PTH がきわ銳敏に分必の抑制を示したこ とからもこの事実が推定できる。一方，C-PTH 值はカ ルシゥムの変動に対してほとんど变化しない．今回の カルシウム負荷に対応して有意の変化を示さなかった ことからも明らかである。 そのため, intact-PTHは変 動幅が大きく，有意差が得られなかった反面，C-PTH は変動幅が少ないため有意差が得られたといいらるだ ろう．採血条件を一定にするか，あるいは今回の検討 のごとくカルシゥム負荷に対する intact-PTH の分泌 の変動をみることが，必要であると思われる。

以上の理由から，続発性上皮小体機能進症の手術 適応の決定にはカルシゥム負荷試験による intact$\mathrm{PTH}$ の分泌抑制の程度を判定の一つの条件とするの が望ましい，カルシゥム負荷 1 時間の段階で前值の $55 \pm 5.6 \%$ でしか抑制がかからない症例は, 1 グラム 以上の重量を呈し, 且つ, 組織学的には nodular hyperplasia である可能性が高く，手術適応と考えたい。

なお，堅不全に対し持続的カルシウム負荷を行らと 異所性石灰化の起こる頻度が高くなることは否定し得 ないか，今回の上5な負荷試験は 1 回のみの検查でカ ルシゥム負荷量は過大なものでない，また，透析時に 実施すれば水負荷も危険もなものでなく, 安全に実施 しうる.

\section{結論}

1. 堅性上皮小体機能六進症における術前のカルシ ウム負荷試験で，血奬 intact-PTH 値の分泌抑制につ いては，摘出上皮小体重量が 1 グラム以上の群では前 値の $55 \pm 5.6 \%$ にどまったが, 1 グラム以下の群では $33 \pm 4.9 \%$ をで抑制され，両群間で有意の差が認められ た.

2. 摘出上皮小体重量が 1 グラム以上の群では病理 組織学的に nodular hyperplasia 像を呈することが頻 度として有意に多く，1ダラム以下の群ではdiffuse hyperplasia 像を呈することが有意に多かった。

3. 組織学的に nodular hyperplasia を示した症例 は手術適応と考えられ，一方， diffuse hyperplasia 像 を呈した症例は保存的治療の対象と考えられた。

4. カルシウム負荷試験により intact-PTH の分泌 
抑制の程度を評価することで，両者の鑑別が可能と思 われた。

\section{文献}

1) Slatopolsky E, Weerts C, Thielan J, et al : Marked suppression of secondary hyperparathyroidism by intravenous administration of 1 , 25-dihydroxycholecalciferol in uremic patients. J Clin Invest $74: 2136-2143,1984$

2) Tsukamoto $Y$, Nomura M, Takahashi $Y$, et al : The oral 1,25-dihydroxyvitamin $D_{3}$ pulse therapy' in hemodialysis patients with severe secondary hyperparathyroidism. Nephron $57: 23-28$, 1991

3）小原孝男, 藤本吉秀, 西 常博：透析患者の副甲状 腺摘除訹。臨透析 $1: 801-813,1985$

4）園田孝男, 小出卓生, 岡 聖次他：続発性上皮小体 譏能元進应. 内分泌外科 $3: 329-334,1986$

5）高木 弘，河合真千夫，加納忠行他：堅性骨異栄養 㱏に対する上皮小体摘出術一亜全摘術上全摘後自 家移植術の比較検討. 堅と骨代謝 2 ：25-35, 1989

6）富永芳博，田中勇治，高木 弘：続咇性上皮小体機 能元進症一手術適応と治療方針. 外科診療 29 : $178-186,1987$

7）前田光信：留性上皮小体機能六進症の外科治療に 関する臨床的研究. 日内分泌会誌 $60: 207-227$, 1984

8）内田久則：続発性上皮小体機能六進症. 頸部-甲状 腺・上皮小体の外科一手術適応と手術の基本一. 日 本外科学会教育委員会編 35. 中外医学社, 1989 , p75-85
9）内田久則，西村洋治，秋山七千男他：腎性上皮小体 機能穴進症における Ca 負荷試験, 術前生化学検 查と摘出上皮小体重量との相互関俰。内分泌外科 : 71-76, 1990

10）信楽園病院腎センター：第 14 章（28）骨・カルシ ウム代謝異常. 平沢由平編著，透析療法マニュフ ル改訂第 3 版, 日本メジカルセンター, 東京, 1989, p $260-263$

11）下条文武，本間則行，丸山弘樹他：アミロイド骨・ 関節症. 1. 骨関節症と $\beta 2 \cdot$ microglobulin. 前田貞 完，他編著，透析患者の骨病变，その見方と考方方 第 3 版、日本メジルセンター，東京，1988，p269 $-290$

12) Martin KJ, Hrusuka KA, Freitag JJ, et al : The peripheral metabolis, of parathyroid hormone. N Engl J Med 301 : 1092-1098, 1979

13) Canterbury JM, Bricker LA, Levey GS, et al : Metabolism of bovine parathyroid hormone. Immunological and biological characteristics of fragments generated by liver perfusion. J Clin Invest 55 : 1245-1253, 1975

14) Togashi $K$, Takahashi $N$, Ando $K$, et al : Comparison of different parathyroid hormone radioimmunoassays in uremic patients with secondary hyperparathyroidism. Int J Artifi Organs $13: 77-82,1990$

15）信楽園病院留センター：第 7 章 (4) 透析液の種類 と組成. 透析療法マニュアル改訂第 3 版, 平沢由平 編著，日本メジカルセンター，東京，1989，p106 $-107$ 


\title{
PARATHYROIDECTOMY FOR SECONDARY HYPERPARATHYROIDISM IN CHRONIC RENAL FAILURE WITH SPECIAL EMPHASIS ON PREOPERATIVE CALCIUM INFUSION STUDY
}

\author{
Hisanori UCHIDA, Hisayuki SUGIMOTO, Yoji NISHIMURA, Shiro HUKUSHIMA, Takahisa SAIRENII, \\ Kazuhiko MEIKATA, Naoya ICHIKAWA, Shinji TOMIKAWA, Takeshi NAGAO, \\ Ken MATSUI*, Toji OSAKABE* and Akira KAKITA*
}

Department of Surgery and Organ Transplantation, The Institute of Medical Science, The University Tokyo *Department of Surgery, Faculty of Medicine, The University of Kitasato

In order to clarify whether or not the preoperative calcium infusion study is useful for determination of an indication for parathyroidectomy on renal hyperparathyroidism, 50 patients were analyzed retrospectivley.

Forty three patients (group 1) demonstrated that weight of the removed parathyroid was more than 1 gram (mean weight: $3.87 \pm 0.42 \mathrm{SE}$ grams). The remaining seven patients (group 2), had the parathyroid of less than 1 gram in weight (mean weight: $0.81 \pm 0.05 \mathrm{SE}$ grams). In patients of group 1, preoperative calcium infusion study revealed $55 \pm 5.6 \%$ suppression of plasma intact PTH level at 1 hour after calcium infusion. On the other hand, the suppression of plasma intact PTH level at 1 hour reached to $33 \pm 4.9 \%$ in patients of group 2 . The results were significantly different $(p<0.01)$. The parathyroids of more than $1 \mathrm{gram}$ in weight showed nodular hyperplastic change rather than diffuse hyperplasia, whereas those of less than $1 \mathrm{gram}$ in weight showed diffuse hyperplastic pattern, with a significant difference $(p<0.05)$. It is thought that patients having the parathyroid of nodular hyperplasia with more than $1 \mathrm{gram}$ in weight can be possible candidates for operation and those of diffuse hyperplasia with less than 1 gram in weight can be indicated for medical treatment. For differentiation of these two situations preoperative calcium infusion study can offer an additional valuable information. 